\title{
AKIBAT HUKUM PELANGGARAN KEWAJIBAN MENGGUNAKAN BAHASA INDONESIA DALAM PERJANJIAN DENGAN PIHAK ASING
}

\author{
Ni Made Ayu Pasek Dwilaksmi ${ }^{1}$ \\ ${ }^{1}$ Program Studi Magister Kenotariatan, Fakultas Hukum Universitas Udayana, \\ E-mail: ayu.dwilaksmi@yahoo.com
}

\begin{tabular}{l}
\hline Info Artikel \\
\hline Masuk : 23 September 2019 \\
Diterima :28 September 2019 \\
Terbit : 30 April 2020 \\
Keywords : \\
Breach, Agreement, Foreign, \\
Indonesian \\
\\
Corresponding Author: \\
Ni Made Ayu Pasek \\
Dwilaksmi, E-mail: \\
ayu.dwilaksmi@yahoo.com \\
DOI : \\
10.24843/AC.2020.v05.i01.p08 \\
Kata kunci: \\
Asinggaran, Perjanjian, \\
\end{tabular}

\begin{abstract}
Indonesian is the national language as regulated in Act Number 24 of 2009. Therefore Indonesian language must be used for formal matters, one of which is in the context of the formulation of the agreement. In fact, in Indonesia there are agreements that use foreign languages, especially agreements involving foreign citizens in it. The purpose of writing this journal is to find out and analyze the arrangements regarding foreign language agreements in Indonesia and the legal consequences of violating the obligation to use the national language of Indonesia in agreements with foreign parties. This journal is doctrinal (normative) which uses a statutory and conceptual approach. Legal materials consist of primary and secondary legal materials which are then analyzed qualitatively. The conclusions that can be obtained in this journal include: (1) Arrangements regarding foreign language Act Number 24 of 2009 which basically stipulates that an agreement must use Indonesian language and must also use a foreign language rather than a foreign party. it originates; (2) Violation of the obligation to use Indonesian in an agreement with a foreign party is not regulated in Act Number 24 of 2009. However, if it is guided by the theory of interpretation of the legislation, namely a systematic interpretation, that the agreement that does not use Indonesian is a prohibited cause as referred to in Article 1320 and Article 1337 of the Civil Code. Therefore, the objective conditions in the agreement were not fulfilled and the agreement was considered null and void.
\end{abstract}

\begin{tabular}{l}
\hline Abstrak \\
\hline Bahasa Indonesia merupakan bahasa nasional \\
sebagaimana diatur dalam Undang-Undang Nomor 24 \\
Tahun 2009. Oleh karenanya bahasa Indonesia wajib \\
digunakan untuk hal-hal yang bersifat formal, salah \\
satunya dalam konteks perumusan perjanjian. Faktanya, di \\
Indonesia ada perjanjian yang menggunakan bahasa asing, \\
khususnya perjanjian yang melibatkan pihak warga negara \\
asing di dalamnya. Adapun tujuan dari penulisan jurnal \\
ini yakni mengetahui dan menganalisis tentang \\
pengaturan mengenai perjanjian berbahasa asing di \\
Indonesia serta akibat hukum atas tindakan pelanggaran \\
terhadap kewajiban menggunakan bahasa nasional negara \\
indonesia dalam perjanjian dengan pihak asing. Jurnal ini
\end{tabular}




\begin{abstract}
bersifat doktrinal (normatif) yang menggunakan pendekatan perundang-undangan dan pendekatan konseptual. Bahan hukum terdiri atas bahan hukum primer dan bahan hukum sekunder yang selanjutnya dianalisis secara kualitatif. Adapun kesimpulan yang dapat diperoleh dalam jurnal ini, antara lain: (1) Pengaturan mengenai perjanjian berbahasa asing di Indonesia diatur pada Pasal 31 Undang-Undang Nomor 24 Tahun 2009 yang pada pokoknya mengatur bahwa suatu perjanjian wajib memakai bahasa Indonesia dan harus juga menggunakan bahasa asing daripada pihak asing itu berasal; (2) Pelanggaran terhadap kewajiban menggunakan bahasa Indonesia di dalam perjanjian dengan pihak asing tidak diatur dalam Undang-Undang Nomor 24 Tahun 2009. Namun jika berpedoman pada teori Penafsiran Perundang-Undangan, yakni penafsiran sistematikal, bahwa terhadap perjanjian yang tidak menggunakan bahasa Indonesia merupakan suatu sebab yang terlarang sebagaimana dimaksud dalam Pasal 1320 dan Pasal 1337 KUHPerdata. Oleh karenanya, syarat obyektif dalam perjanjian tidk terpenuhi dan perjanjian tersebut dianggap batal demi hukum.
\end{abstract}

\title{
1. Pendahuluan
}

Bahasa Indonesia menjadi bahasa nasional di Negara Indonesia, ini merupakan perjuangan para pemuda dalam "Kongres Pemuda" yang dilangsungkan di Jakarta pada tahun 1928 tepat pada bulan Oktober, ikrar ketiga dalam sumpah pemuda tersebut menghasilkan bahwa untuk mempersatukan bangsa Indonesia harus menggunakan bahasa Indonesia, dan para pemuda sepakat menentukan bahasa nasional negara Indonesia yaitu dengan nama "Bahasa Indonesia". Bahasa nasional bermula dari bahasa melayu. Sumpah Pemuda menginspirasi atas semangat nasionalisme kaum pemuda dan pelajar serta mengangkat derajat dan martabat bahasa Indonesia serta menghilangkan unsur atau kesan kedaerahan daripada bahasa melayu itu sendiri. Saat ini Bahasa Indonesia mengalami kemajuan yang sangat pesat, baik dalam bentuk tulis maupun lisan dari sejak zaman penjajahan hingga pada zaman globalisasi saat ini. Bahasa Indonesia sendiri berfungsi sebagai identitas negara, alat penghubung bagi warga, bagi daerah serta budaya, alat pengembangan kebudayaan, ilmu pengetahuan dan teknologi. Namun seiring berjalannya waktu, jaman globalisasi menerjang seluruh dunia dengan cepat, Negara Negara yang dulu serasa sangat jauh untuk di jangkau, saat ini kondisinya Negara -negara di dunia sudah tidak ada batasnya lagi berkat kemajuan teknologi. Masuknya bahasa asing ke Indonesia telah menjadi bagian sehari hari masyarakat Indonesia, yang sekaligus memberikan penetrasi dengan pertahap memasuki hal-hal formal di indonesia. Bahasa asing juga kini banyak terdapat pada perjanjian-perjanjian yang di buat di Indonesia, perjanjian 
dengan bahasa asing bukan merupakan hal yang tabu lagi di Indonesia, sehingga hal itu tidak mengherankan lagi terjadi di Indonesia. Bahasa yang paling sering dipergunakan yaitu bahasa inggris, mengingat bahasa inggris merupakan bahasa internasional. Perjanjian dengan bahasa asing ini biasanya dibuat jika melibatkan pihak asing.

Kata "Perjanjian" menjadi suatu kata yang tidak asing lagi bagi kehidupan manusia dimuka bumi, begitu juga di Indonesia. Di dalam Pasal 26 Konvensi Wina 1969 yang menyatakan bahwa "every treaty in force is binding upon the parties to it and must be performed by them in good faith" yang dapat dimaknai bahwa "setiap perjanjian mengikat para pihak dan harus dilaksanakan dengan itikad baik". ${ }^{1}$

Polemik tentang perjanjian terjadi di Indonesia setelah di Undangkanya "Undang-Undang Nomor 24 Tahun 2009 tentang Bendera, Bahasa dan Lambang Negara Serta Lagu Kebangsaan" (pada tulisan ini disingkat menjadi UU 24 Tahun 2009). Pada UU 24 Tahun 2009 ini terdapat Pasal yang menerangkan bahwa menggunakan bahasa Indonesia adalah wajib hukumnya dalam perjanjian-perjanjian yang diibuat di Indonesia, sebagaimana diatur pada Pasal 31 UU 24 Tahun 2009. Sejak di undangkan pada tanggal 9 Juli 2009 tersebut, menimbulkan reaksi beragam di kalangan pengacara dan pengusaha menanyakan keabsahan dan kepastian hukum daripada perjanjian yang mereka buat selama ini, karena praktek yang sering mereka lakukan dengan membuat perjanjian dengan pihak asing dengan hanya menggunakan bahasa asing saja, biasanya menggunakan bahasa inggris. Karena pada UU 24 tahun 2009 tersebut tidak satupun dibahas atau diatur menganai sanksi apabila melanggar kewajiban untuk menggunakan bahasa Indonesia dalam perjanjian dengan pihak asing. Ini menjadikan celah untuk melanggar apa yang menjadi ketentuan Pasal 31 UU 24 Tahun 2009 ini. Kemudian di sisi lain Kementerian Hukum dan Ham Republik Indonesia merespon reaksi tersebut dengan mengeluarkan Surat Edaran Menteri Hkum dan HAM. Melalui suratnya bernomor M.HH.UM.01.01-35 perihal "Permohonan Klarifikasi atas implikasi dan pelaksanaan UU 24 Tahun 2009", dinyatakan bahwa perjanjian privat komersial (private commercial agreement) dalam bahasa Inggris tidak disertai versi bahasa Indonesia dan tidak melanggar persyaratan kewajiban seperti ditentukan Undang Undang tersebut. Sampai adanya peraturan pelaksanaan dari pada UU 24 Tahun 2009 tersebut". ${ }^{2}$

\footnotetext{
1 Paramarta, I. G. B. A. A., Putra, I. B. W., \& Utari, N. K. S. (2017). Akibat Hukum Perjanjian Lisensi Terhadap Pihak Ketiga. Acta Comitas: Jurnal Hukum Kenotariatan. 2(1). 75-83. h. 77

2 Ali, Hukum Online, 2010, "Menkumham : Perjanjian Berbahasa Inggris Tetap Sah", Hukum Online.com, URL

https://www.hukumonline.com/berita/baca/lt4b6a1df8b9cbf/menkumham-perjanjianberbahasa-inggris-tetap-sah/ , diakses pada tanggal 6 Agustus 2019, Pukul 9:39
} 
Kekosongan norma ini membuat apa yang menjadi akibat hukum apabila terjadi pelanggaran atas kewajiban menggunakan bahasa Indonesia dalam suatu perjanjian dengan pihak asing di Indonesia akibat hukum ini penting untuk dibahasa karena akibat hukum ini nantinya akan bermuara kepada kepastian hukum pada Pasal 31 UU 24 Tahun 2009. Sehingga berdasarkan permasalahan yang dikemukakan maka relevan dilakukan penulisan berjudul "AKIBAT HUKUM PELANGGARAN KEWAJIBAN MENGGUNAKAN BAHASA INDONESIA DALAM PERJANJIAN DENGAN PIHAK ASING"

Berdasarkan permasalahan yang telah dikemukakan, sehingga dapat dirumusakan 2 (dua) masalah nantinya akan dibahas dalam jurnal tulisan ini yaitu mengenai bagaimana pengaturan terkait perjanjian berbahasa asing di Indonesia ? dan bagaimana akibat hukum melanggar kewajiban menggunakan bahasa indonesia dalam perjanjian dengan pihak asing?

Penulisan ini agar menjadi berguna dikemudian hari memiliki suatu tujuan yang hendak dicapai, yaitu bertujuan untuk memahami secara umum mengenai akibat hukum pelanggaran kewajiban menggunakan bahasa Indonesia dalam perjanjian dengan pihak asing dan untuk mengetahui secara khusus mengenai pengaturan terkait perjanjian berbahasa asing di Indonesia dan akibat hukum melanggar kewajiban menggunakan bahasa indonesia dalam perjanjian dengan pihak asing.

Penulisan ini dibuat dengan menuangkan pemikiran-pemikiran yang baru dan orisinil guna untuk kemajuan dunia pendidikan, walaupun ditemukan tulisan yang mirip atau serupa dengan tulisan yang lain yang lebih dulu ada, namun tulisan ini tetap memiliki unsur-unsur pembaharuan didalamnya. Tulisan ini menggunakan 2 (dua) tulisan terdahulu menjadi pembandingnya, antara lain :

1) Jurnal yang ditulis oleh Bili Achmad, yang diterbitkan oleh Diponogoro Law Riview Fakultas Hukum Universitas Diponogoro, Vol. 05, No. 02, Tahun 2016. Judul "Keabshan Kontrak Berbahasa Asing Dan Kepastian Terhadap Akibat Hukum Berdasarkan Assas Kebebasan Berkontrak, Menurut Undang Undang No. 24 Tahun 2009 serta Surat Kementerian Hukum Dan Hak Asasi Manusia No : M.Hh.Um.01.01-35 (Studi Putusaan Pengadilan Negeri Jakarta Barat No : 451 / Pdt.G/2012,Pn.Jkt.Bar)." Permasalahan yang diangkat yaitu "mengenai keabsahan kontrak yang tidak menggunakan bahasa indonesia berdasarkan asas kebebasan berkontrak menurut UU Nomor 24 tahun 2009 dan Surat Kementerian Hukum dan Hak Asasi Manusia Nomor: M.HH.UM.01.01-35 dan kepastian hukum terhadap akibat hukum kontrak yang tidak berbahasa Indonesia."

2) Jurnal yang ditulis oleh Fadilla Mariska Putri dan Adi Sulistiyono, yang diterbitkan oleh Privat Law Fakultas Hukum Universitas Sebelas Maret, 
Vol. 06, No. 02, Tahun 2018. Judul “Kepastian Hukum Terhadap Kontrak Bisnis Berbahasa Asing Pasca Berlakunya Undang-Undang Nomor 24 Tahun 2009 Tentang Bendera, Bahasa, Dan Lambang Negara, Serta Lagu Kebangsaan". Permasalahan yang diangkat yaitu mengenai "kepastian hukum terhadap kontrak bisnis berbahasa asing pasca berlakunya Undang-Undang Nomor 24 Tahun 2009 Tentang Bendera, Bahasa, dan Lambang Negara, serta Lagu Kebangsaan."

Berdasarkan perbandingan dengan jurnal atau tulisan yang terdahulu dengan tulisan ini tidak terdapat upaya untuk menjiplak tulisan sebelumnya, namun tetap tulisan ini tetap memiliki unsur pembaharuan didalamnya. Tulisan ini memiliki judul "Akibat Hukum Pelanggaran Kewajiban Menggunakan Bahasa Indonesia Dalam Perjanjian Dengan Pihak Asing". Permasalahan yang dibahas didalamnya yaitu mengenai pengaturan terkait perjanjian berbahasa asing di Indonesia dan akibat hukum melanggar kewajiban menggunakan bahasa Indonesia dalam perjanjian dengan pihak asing.

\section{Metode Penelitian}

Metode Penelitian adalah kegiatan atau cara-cara yang dilakukan secara sistematis serta sangat berkaitan dengan kontruksi dan analisa sesuatu yang hendak diteliti yang tentunya dilakukan dengan cara yang konsisten. ${ }^{3}$ Penelitian ini menggunakan peneliitian hukum normatif, penelitian ini dilakukan dengan cara melakukan penelitian dengan mengkaji norma hukum itu sendiri dan dikaji dengan asas, kaidah serta peraturan perundang-undangan lainya, pendapat pendapat para ahli hukum serta sumber-sumber hukum lainya. 4 Pendekatan yang digunakan ialah pendekatan konsep hukum dan pendekatan perundang-undangan. Pendekatan konsep dimaksudkan yaitu melakukan pengkajian norma hukum terkait dengan konsep hukum yang ada dan relevan untuk menjawab permasalahan yang disediakan. Pendekatan perundang-undangan dilakukan dengan cara-cara mengkaji norma hukum tersebut dengan peraturan perundang undangan terkait dan relevan, pendekatan perundang undangan yang digunakan di dalam penelitian ini ialah dengan melakukan penelusuran norma hukum untuk menjawab apa yang menjadi tujuan penelitian. Pendekatan juga menggunakan hierarki serta asas dari peraturan perundang undangan itu sendiri..$^{5}$ Penelitian menggunakan bahan hukum primer berupa peraturan perundang-undangan yang berhubungan dengan pembahasan, serta menggunakan bahan hukum

\footnotetext{
${ }^{3}$ Soekanto, Soerjono. (2012). Pengantar Penelitian Hukum. Jakarta: Universitas Indonesia Press. h.42

${ }^{4}$ Sugiarto, S. (2018). Penjatuhan Pidana oleh Hakim Terhadap Prajurit Tentara Nasional Indonesia sebagai Pelaku Penyalahguna Narkotika. Jurnal Magister Hukum Udayana (Udayana Master Law Journal), 7(2), 169-170

${ }^{5}$ Setiabudhi, I. K. R., Artha, I. G., \& Putra, I. P. R. A. (2018). Urgensi Kewaspadaan Dini dalam Rangka Memperkuat Persatuan dan Kesatuan Bangsa. Jurnal Magister Hukum Udayana (Udayana Master Law Journal), 7(2), h. 253
} 
sekunder adalah buku-buku literatur terkait yang ada hubunganya serta termutakhir guna mendukung pembahasan pada permasalahan yang ada. ${ }^{6}$ Jurnal-jurnal hukum terkini juga digunakan menjadi bahan hukum pada penelitian ini karena jurnal hukum merupakan penulisan resmi yang tingkat kemutakhiranya sangat cepat diperbaharui, sehingga bahan-bahan penunjang yang didapat merupakan bahan yang terkini.

\section{Hasil Dan Pembahasan}

\subsection{Pengaturan Terkait Perjanjian Berbahasa Asing Di Indonesia}

Perjanjian atau persetujuan bukan saja mengenai segala hal yang telah secara jelas diperjanjikan, tetapi juga menyangkut pada hal-hal yang berdasarkan atas sifat dari persetujuan itu sendiri dapat dituntut atas dasar kebiasaan, keadilan, dan juga atas dasar Undang-Undang. ${ }^{7}$ Menurut Salim H.S, perjanjian memiliki pengertian hukum mengenai keseluruhan antara para pihak yang saling berhubungan, kemudian tertuang keinginan para pihak yang ada pada dokumen tertulis agar tercapainya suatu tujuan tertentu. ${ }^{8}$ Perjanjian adalah "peristiwa nyata dan dapat dilihat wujudnya karena dalam suatu perjanjian kita dapat melihat atau mendengar janji-janji yang diucapkan oleh para pihak yang mengadakan persetujuan atau dapat pula membacanya dalam kalimat yang berisi kata-kata janji yang telah dibuat dan disetujui oleh para pihak dalam suatu perjanjian tertulis." ${ }^{9}$ Jadi alangkah baiknya jika perjanjian dibuat menggunakan bahasa yang mampu dipahami oleh semua pihak, apalagi perjanjian tersebut melibatkan orang asing, guna mengamalkan itikad baik pada pembuatan perjanjian tersebut.

Terkait dalam hal perjanjian berbahasa asing di Indonesia, juga kerap dilakukan oleh warga Negara Indonesia itu sendiri apabila mereka melakukan perjanjian dengan warga Negara Asing yang kerap kali mengunakan bahasa Inggris dalam membuat perjanjianya dan tidak disertai dengan bahasa Indonesia. Semenjak diundangkanya UU 24 Tahun 2009 ini kebiasaan itu harus berubah total. Pasal 31 UU 24 Tahun 2009 mengatur sebagai berikut :

Pasal 31 ayat (1)

"Bahasa Indonesia wajib digunakan dalam nota kesepahaman atau perjanjian yang melibatkan lembaga negara, instansi pemerintah

\footnotetext{
${ }^{6}$ Mahmud Marzuki, Peter. (2005). Penelitian Hukum, Jakarta: Kencana Prenada Media Grup.h.181

7 Purnayasa, A. T. (2018). Akibat Hukum Terdegradasinya Akta Notaris yang Tidak Memenuhi Syarat Pembuatan Akta Autentik. Acta Comitas: Jurnal Hukum Kenotariatan, 3(3), 395-409. h. 402

8 Diputra, I. G. A. R. (2018). Pelaksanaan Perancangan Kontrak dalam Pembuatan Struktur Kontrak Bisnis. Acta Comitas: Jurnal Hukum Kenotariatan, 3(3), 495-560. h. 551

9 Subekti. R. (1980). Aspek-Aspek Hukum Perikatan Nasional. cet 2. Bandung: Alumni.h.10
} 
Republik Indonesia, lembaga swasta Indonesia atau perseorangan warga negara Indonesia."

Pasal 31 ayat (2)

“Nota kesepahaman atau perjanjian sebagaimana dimaksud pada ayat (1) yang melibatkan pihak asing ditulis juga dalam bahasa nasional pihak asing tersebut dan/atau bahasa Inggris."

Berdasarkan Pasal 31 UU 24 Tahun 2009, kebiasaan-kebiasaan orang Indonesia ataupun orang asing dalam membuat perjanjian di Indonesia, dulunya jika membuat perjanjian hanya menggunakan bahasa asing sekarang haruslah menggunakan bahasa Indonesia di dalam membuat perjanjian. Karena Pasal 31 UU 24 Tahun 2009 memiliki makna bahwa suatu perjanjian menggunakan bahasa Indonesia merupakan sebuah kewajiban dan diterjemahkan juga kedalam bahasa pihak asing tersebut, disesuaikan bahasanya dengan bahasa pihak asing itu berasal. Berarti semenjak diundangkanya UU 24 Tahun 2009, apabila membuat perjanjian dengan warga Negara asing atau pihak asing perjanjian harus dibuat dengan dua bahasa, antara lain bahasa Indonesia serta bahasa asing, yang dimana kedua naskah tersebut sama aslinya.

\subsection{Akibat Hukum Pelanggaran Kewajiban Menggunakan Bahasa Indonesia dalam Perjanjian Dengan Piihak Asing}

Akibat hukum adalah akar dari timbulnya kewajiban dan hak bagi subjek hukum yang terkait. ${ }^{10}$ Mencari akibat dalam hukum bagi pihak yang melanggar kewajiban menggunakan bahasa Indonesia dalam perjanjian dengan pihak asing di Indonesia, maka kita akan kesulitan mencari apa akibat hukumnya. Karena pada UU 24 Tahun 2009 tidak satupun Pasal pada UndangUndang tersebut mengatur mengenai sanksi apabila melanggar ketentuan Pasal 31 UU 24 Tahun 2009 tersebut, yang dimana meewajibkan menggunakan bahasa Indonesiia dalam setiap perjanjian.

Sanksi tegas apabila melanggar kewajiban para pihak dalam membuat suatu perjanjian dengan bahasa Indonesia dewasa kini masih belum tersedia di Undang-Undang manapun di Indonesia walaupun sanksi itu belum ada pada hukum positif di Indonesia, yang terlihat memberikan peluang dan titik lemah bagi penerapan Undang-Undang tersebut, sehingga pihak-pihak yang membuat perjanjian itu tetap membuat perjanjian dengann bahasa asing saja. Menjawab permasalahan itu, teori hukum terkait dapat digunakan dalam masalah yang dimana tidak ada aturannya pada hukum positif Indonesia. Teori hukum yang terkait dengan permasalahan digunakan guna mencari jawaban atas kebuntuan yang terjadi, dapat menggunakan teori yang telah popular

10 Antari, N. L. Y. S. (2018). Pembatalan Perjanjian Pengikatan Jual Beli Hak Milik Atas Tanah. Acta Comitas: Jurnal Hukum Kenotariatan, 3(2), 280-290.h. 286 
didunia terkait dengan perjanjian, terkait dengan akibat hukum apa yang dapat diterapkan pada perjanjian yang dibuat di Indonesia, namun tidak menggunakan bahasa Indonesia padahal perjanjian melibatkan orang Indonesia dan orang asing yang mengakibatkan perjanjian tersebut wajib tunduk pada hukum yang berlaku di Indonesia, yaitu wajib menggunakan bahasa nasional Indonesia pada setiap perjanjian yang akan dibuat di Indonesia.

Teori hukum yang dimaksud adalah dengan menggunakan Teori Penafsiran Perundang-undangan yaitu penafsiran sistematikal, yang dirumuskan sebagai berikut : "tidak sebuah pun dari peraturan dapat ditafsirkan seolah-olah berdiri sendiri". ${ }^{11}$ Penafsiran sistematikal dapat bermakna bahwa suatu aturan selalu memiliki hubungan dengan aturan yan lainya, dan ini terjadi juga pada UU 24 Tahun 2009, bahwa aturan tersebut tidak bisa berdiri sendiri, aturan tersebut harus kembali pada rujukanya yaitu Buku III KUHPerdata yaitu pada bagian syarat sah nya suatu perjanjian, agar kita bisa menganalisa dan menilai apa akibat hukumnya bagi pelanggar kewajiban menggunakan bahasa Indonesiia dalam perjanjian dengan pihak asing. Syarat sahnya suatu perjanjian diatur pada Pasal 1320 KUHPerdata, yang diamana terdiri dari 4 (empat) unsur yang dimana dirumuskan sebagai berikut :

1. “sepakat mereka yang mengikatkan diri;

2. kecakapan untuk membuat suatu perikatan;

3. suatu hal tertentu;

4. suatu sebab yang halal."12

Keempat syarat/unsur sahnya perjanjian ini memiliki sifat yang kolektif, yang artinya keseluruhan unsur ini harus dipenuhi jika perjanjian itu ingin disebut sebagai perjanjian yang sah. Syarat sahnya perjanjian berlaku secara kolektif, artinya dalam suatu perjanjian tersebut keempat syarat tersebut haruslah terpenuhi secara keseluruhanya, tidak boleh kurang satupun. Jadi apabila satu syarat saja tidak terpenuhi maka akibat hukumnya antara "batal demi hukum" atau "dapat dibatalkan".

Akibat hukum syarat subjektif tidak terpenuhi yaitu syarat "sepakat mereka yang mengikatkan diri" dan/atau "kecakapan untuk membuat suatu perikatan" maka akibat hukumnya adalah dapat dibatalkan. Syarat "sepakat mereka yang mengikatkan diri" ditandai dengan menerima penawaran dari para pihak yang dibuat secara tertulis yang dapat dituangkan di dalam bentuk akta otentik ataupun akta dibawah tangan yang ditandatangai oleh pihakpihak. Kemudian syarat "kecakapan untuk membuat suatu perikatan" yang memilki arti bahwa orang yang cakap membuat perjanjian yaitu orang yang cakap dalam hukum dan tidak termasuk kepada orang belum dewasa dalam

\footnotetext{
11 Bhakti, Ardhiwisastra Yudha. (2008). Penafsiran dan Konstruksi Hukum. Bandung: Alumni.h. 10 12 Triashari, N. W. (2018). Kekuatan Hukum Perseujuan Suami atau Istri yang dibuat di Bawah Tangan. Acta Comitas: Jurnal Hukum Kenotariatan, 3(3), 500-510. h. 503
} 
hal ini belum melewati 21 tahun, orang yang menurut putusan pengadilan dalam kondisi pengampuan, dan perampuan yang dalam kondisi sebagaimana ditetapkan oleh Undang-Undang. Apabila hal-hal tersebut tidak memenuhi syarat maka perjanjian itu dapat dibatalkan.

Sedangkan, bila syarat objektif tidak terpenuhi yaitu syarat "suatu hal tertentu" dan/atau "suatu sebab yang halal" maka, akibat hukum nya adalah batal demi hukum. Syarat "suatu hal tertentu", artinya pada perjanjian harus ada objek atau benda yang dapat diperjanjikan baik berupa benda bergerak maupun tidak bergerak yang dapat bernilai uang dan dapat berupa jasa yang dapat dinilai dengan kualitas perbuatanya. ${ }^{13}$ Syarat "suatu sebab yang halal" adalah sebab-sebab dari hadirnya objek tersebut haruslah sesuai dan tidak bertentangan dengan Undang-Undang, kebiasaan, ketertiban umum, kepatutan dan kesusilaan. Apabila perjanjian itu dibuat dengan benda yang sebab ataupun asal muasalnya bertentangan dengan Undang-Undang atau dapat dikatakan tidak halal, maka perjanjian tersebut ada pada kondisi batal demi hukum, yang kemudian maksud daripada batal demi hukum yaitu kembali pada kondisi semula atau dianggap sama sekali tidak pernah terjadi suatu perjanjian tersebut. ${ }^{14}$

"Sebab yang halal" merupakan salah satu dari beberapa syarat-syarat sahnya suatu perjanjian. Kemudian Pasal 1337 KUHPerdata menetapkan sebab sebab apa saja yang dilarang atau tidak diperbolehkan, yang salah satunya adalah sebab yang dilarang oleh Undang Undang, yang artinya perjanjian tidak boleh melanggar kaedah yang diatur oleh Undang-Undang, walaupun ada asass kebebasan berkontrak. UU Nomor 24 Tahun 2009, dalam Pasal 31, memang tidak secara tersurat menyebutkan "dilarang untuk tidak menggunakan bahasa Indonesia dalam perjanjian". Aturan kewajiban menggunakan bahasa Indonesia dalam suatu perjanjain merupakan suatu aturan atau kaidah yang harus dipatuhi oleh seluruh rakyat Indonesia, dan orang asing yang berada di Indoensia karena orang asing itu berada pada yurisdiksi Indonesia, yang kemudian bermakna logis bahwa bila suatu perjanjian tidak berbahasa Indonesia, dapat dikatakan bahwa perjanjian itu melanggar Undang-Undang yang ada dan hal tersebut sudah melanggar syarat "sebab yang halal" pada syarat sahnya suatu perjanjain atau dapat diikatakan perjanjiani tersebut meengandung hal-hal yang terlarang karena tiidak mengunakan bahasa Indonesia. Apabila suatu perjanjian yang dibuat di Indonesia dan tidak menggunakan bahasa Indonesia, maka perjanjain tersebut batal demi hukum

\footnotetext{
${ }^{13}$ Artadi,I.K.,\& Rai Asmara Putra,I.D.N. (2014). Implementasi Ketentuan-ketentuan Hukum Perjanjian Kedalam Perancangan Kontrak, Denpasar: Udayana University Press. h.58.

${ }^{14}$ Sunanda, B., Wahab, A. A., \& Abubakar, M. (2013). Pembatalan Perjanjian Jual Beli Tanah Meskipun Telah Memiliki Akta Jual Beli Tanah Dari PPAT OLeh Pengadilan Negeri. Jurnal Ilmu Hukum ISSN, 2302, 0180. 106-115. h. 109
} 
dan dianggap perjanjian tersebut tidak pernah terjaadi karena telah melanggar syarat objektif yaitu "sebab yang halal". 15

\section{Kesimpulan}

Pengaturan mengenai perjanjian berbahasa asing di Indonesia diatur pada Pasal 31 UU 24 Tahun 2009 memiliki makna bahwa suatu perjanjian wajib memakai bahasa Indonesia dan harus juga menggunakan bahasa asing daripada pihak asing itu berasal. Berarti semenjak diundangkanya UU 24 Tahun 2009, apabila membuat perjanjian dengan warga Negara asing atau pihak asing perjanjian harus dibuat dengan 2 bahasa, yaitu bahasa Indonesia serta bahasa asing, yang dimana kedua naskah tersebut sama aslinya.

Akibat hukum daripada pelanggaran terhadap kewajiban menggunakan bahasa Indonesia di dalam perjanjian dengan pihak asing tidak diatur didalam UU 24 Tahun 2009, tidak satupun dari pasal-pasal yang terdapat pada UU 24 Tahun 2009 ini membahas mengenai sanksi terkait pelanggaran terhadap kewajiban menggunakan bahasa Indonesia di dalam perjanjian dengan pihak asing. Namun, dengan menggunakan Teori Penafsiran Perundang-Undangan yaitu penafsiran sistematikal, bahwa dengan tidak menggunakan bahasa Indonesia pada perjanjian dengan pihak asing, merupakan suatu sebab yang terlarang karena melanggar apa yang dilarang Undang-Undang, ini terkait dengan Pasal 1320 dan Pasal 1337 KUHPerdata, jadi bahwa apabila seseorang tidak menggunakan bahasa Indonesia dalam membuat perjanjian dengan pihak asing, maka sebab yang halal sebagai syarat sahnya suatu perjanjain tidak dapat tercapat, karena sebab yang terlarang melanggar syarat objektif sahnya suatu perjanjian, jadi pelanggaran terhadap kewajiban mengunakan bahasa Indonesia dalam perjanjain dengan pihak asing batal demi hukum.

\section{Daftar Pustaka}

$\underline{\text { Buku }}$

Bhakti, Ardhiwisastra Yudha. (2008). Penafsiran dan Konstruksi Hukum. Bandung: Alumni.

Subekti. R. (2004). Hukum Perjanjian. Jakarta: PT Intermasa.

Subekti. R. (1980). Aspek-Aspek Hukum Perikatan Nasional. cet 2. Bandung: Alumni.

Soekanto, Soerjono. (2012). Pengantar Penelitian Hukum. Jakarta: Universitas Indonesia Press.

Artadi,I.K.,\& Rai Asmara Putra,I.D.N. (2014). Implementasi Ketentuan-ketentuan Hukum Perjanjian Kedalam Perancangan Kontrak, Denpasar: Udayana University Press.

Mahmud Marzuki, Peter. (2005). Penelitian Hukum, Jakarta: Kencana Prenada Media Grup.

${ }^{15}$ Subekti, R.(2004). Hukum Perjanjian. , Jakarta : PT Intermasa. h. 20 


\section{Jurnal Ilmiah}

Antari, N. L. Y. S. (2018). Pembatalan Perjanjian Pengikatan Jual Beli Hak Milik Atas Tanah. Acta Comitas: Jurnal Hukum Kenotariatan, 3(2), 280-290.

Diputra, I. G. A. R. (2018). Pelaksanaan Perancangan Kontrak dalam Pembuatan Struktur Kontrak Bisnis. Acta Comitas: Jurnal Hukum Kenotariatan, 3(3), 495-560. h. 551.

Paramarta, I. G. B. A. A., Putra, I. B. W., \& Utari, N. K. S. (2017). Akibat Hukum Perjanjian Lisensi Terhadap Pihak Ketiga. Acta Comitas: Jurnal Hukum Kenotariatan. 2(1). 75-83. h. 77.

Purnayasa, A. T. (2018). Akibat Hukum Terdegradasinya Akta Notaris yang Tidak Memenuhi Syarat Pembuatan Akta Autentik. Acta Comitas: Jurnal Hukum Kenotariatan, 3(3), 395-409.

Setiabudhi, I. K. R., Artha, I. G., \& Putra, I. P. R. A. (2018). Urgensi Kewaspadaan Dini dalam Rangka Memperkuat Persatuan dan Kesatuan Bangsa. Jurnal Magister Hukum Udayana (Udayana Master Law Journal), 7(2), 253.

Sugiarto, S. (2018). Penjatuhan Pidana oleh Hakim Terhadap Prajurit Tentara Nasional Indonesia sebagai Pelaku Penyalahguna Narkotika. Jurnal Magister Hukum Udayana (Udayana Master Law Journal), 7(2), 169-170.

Sunanda, B., Wahab, A. A., \& Abubakar, M. (2013). Pembatalan Perjanjian Jual Beli Tanah Meskipun Telah Memiliki Akta Jual Beli Tanah Dari PPAT OLeh Pengadilan Negeri. Jurnal Ilmu Hukum ISSN, 2302, 0180. 106-115.

Triashari, N. W. (2018). Kekuatan Hukum Perseujuan Suami atau Istri yang dibuat di Bawah Tangan. Acta Comitas: Jurnal Hukum Kenotariatan, 3(3), 500-510.

\section{Peraturan Perundang-undangan}

Kitab Undang-Undang Hukum Perdata, 2009, Burgerlijk Wetboek, diterjemahkan oleh Prof. R.Subekti, SH dan R.Tjitrosudibio, Cetakan ke Empatpuluh, Pradnya Paramita, Jakarta.

Republik Indonesia, 2009, Undang-Undang Republik Indonesia, Nomor 24 Tahun 2009 Tentang Bendera, Bahasa dan Lambang Negara, Serta Lagu Kebangsaan (Lembaran Republik Indonesia Tahun 2009 Nomor 109, Tambahan Lembaran Negara Republik Indonesia Nomor 5035).

\section{$\underline{\text { Website }}$}

Ali, Hukum Online, 2010, “Menkumham : Perjanjian Berbahasa Inggris Tetap Sah", Hukum Online.com, URL https://www.hukumonline.com/berita/baca/lt4b6a1df8b9cbf/menku mham-perjanjian-berbahasa-inggris-tetap-sah/ , diakses pada tanggal 6 Agustus 2019, Pukul 9:39 